\title{
Pengembangan Bahan Ajar Teks Anekdot Untuk Sekolah Menengah Kejuruan Kelas X
}

\author{
Sri Utami ${ }^{1}$ \\ ${ }^{1}$ Dosen Prodi Pendidikan Bahasa Indonesia, Universitas Nahdlatul Ulama Blitar \\ Email: ${ }^{1}$ utami3215@gmail.com
}

\begin{tabular}{l}
\hline Tersedia Online di \\
\hline $\begin{array}{l}\text { http://www.jurnal.unublitar.ac.id/ } \\
\text { index.php/briliant }\end{array}$ \\
\hline Sejarah Artikel \\
\hline Diterima pada 30 Januari 2018 \\
Disetuji pada 8 Februarii 2018 \\
Dipublikasikan pada 13 Februari \\
2018 Hal. 51-60 \\
\hline
\end{tabular}

Kata Kunci:

bahan ajar, makna tersirat, teks anekdot

\section{DOI:}

http://dx.doi.org/10.28926/briliant .v3i1.136

\begin{abstract}
Abstrak: Bahan ajar secara garis besar terdiri atas pengetahuan, keterampilan, dan sikap yang harus dipelajari peserta didik untuk mencapai standar kompetensi yang telah ditentukan. Bahan ajar yang dikembangkan berupa bahan cetak yang memuat makna tersirat berupa sindiran atau kritik dalam anekdot. Tujuan utama teks anekdot adalah untuk menyampaikan kritik atau sindiran dalam bentuk cerita yang lucu. Adapun tujuan khusus penelitian ini menghasilkan produk bahan ajar cetak pembelajaran teks anekdot berupa buku ajar yang berisi pengantar, kegiatan inti, dan refleksidan mendeskripsikan kelayakan yang meliputi tingkat validitas, kepraktisan, kemenarikan, dan efektivitas produk bahan ajar teks anekdot untuk SMK kelas $\mathrm{X}$.
\end{abstract}

Kurikulum 2013 revisi 2017 diterapkan pada tahun 2017 pada sekolah menengah kejuruan yang sebelumnya menerapkan Kurikulum Tingkat Satuan Pendidikan (KTSP) atau kurikulum 2006. Meskipun demikian terdapat beberapa sekolah menengah kejuruan yang digunakan sebagai model penerapan Kurikulum 2013. Di Kabupaten Kediri Provinsi Jawa Timur, sekolah yang dijadikan model Kurikulum 2013 sebelum tahun 2017 adalah SMK Bhakti Mulia Pare, SMK YP 17 Pare, dan SMK Pawiyatan Dhaha 3. SMK berstatus negeri di Kabupaten Kediri tidak ada yang dijadikan sekolah model Kurikulum 2013, termasuk SMK Negeri 1 Semen. Sekolah tersebut masih menerapkan Kurikulum 2006.

Sampai tiba pelaksanaan Kurikulum 2013 revisi 2017 yang dilakukan serentak seluruh Indonesia, guru bahasa Indonesia melakukan bimbingan teknis implementasi kurikulum 2013 revisi 2017. Guru-guru ini dilatih untuk mahir dalam pembelajaran, termasuk guru SMKN 1 Semen yang dijadikan sumber penelitian. Dari informasi yang didapat dari guru, buku penunjang Kurikulum 2013 revisi 2017 SMK belum sampai ke sekolah tersebut karena pada beberapa penerbit rekanan Kemendikbud telah kehabisan stok buku. Guru menggunakan buku bahasa Indonesia Kurikulum 2013 versi lama sebagai alternatif pemebalajaran berbasis teks. Keterbatasan buku tersebut juga memaksa guru untuk menggandakan bagian teks yang akan dipelajari. Buku referensi belajar menjadi kendala utama dalam proses pembelajaran, mengingat kurikulum 2013 revisi 2017 yang berbeda dengan kurikulum 2013 versi sebelumnya.

Berdasarkan observasi yang dilakukan pada peserta didik kelas X SMK Negeri 1 Semen Kabupaten Kediri pada tanggal 5 September 2018, menunjukkan 
bahwa pembelajaran menganalisis dan mengonstruksi makna tersirat teks anekdot dilakukan dengan konvensional. Guru belum sepenuhnya menerapkan pendekatan saintifik dan model pembelajaran sesuai Kurikulum 2013 revisi 2017. Selain itu, terdapat kendala bagi guru untuk menerapkan pembelajaran berbasis teks ini. Sebelum pembelajaran, guru mencari-cari teks anekdot dari berbagai sumber. Kemudian, teks yang didapat guru akan dibagikan ke peserta didik untuk difotokopi agar semua peserta didik mendapatkan bahan belajar tersebut. Guru juga masih dominan memberikan ceramah terkait materi teks anekdot. Peserta didik belum dapat dilepaskan sendiri untuk memahami konsep karena peserta didik SMKN 1 Semen Kabupaten Kediri belum ada referensi apapun. Buku peserta didik dari pemerintah untuk bahan belajar belum diterima sekolah tersebut.

Berdasarkan hasil wawancara dengan beberapa peserta didik kelas $\mathrm{X}$, mereka menginginkan pembelajaran teks anekdot memiliki kriteria yang menarik, yaitu (1) guru secara aktif memandu peserta didik dalam setiap langkah pembelajaran, (2) Guru meminimalisir ceramah, (3) Buku panduan belajar Kurikulum 2013 revisi 2017 yang runtut sesuai tujuan belajar, (4) isi teks anekdot yang mancakup berbagai bidang kehidupan. Berdasarkan pengamatan peneliti, peserta didik belum memiliki referensi baik berupa Lembar Kerja Peserta didik (LKS) maupun buku paket yang dapat dibawa pulang oleh peserta didik.

Dari hasil temuan permasalahan di atas, perlu dilakukan upaya untuk memecahkan masalah. Selayaknya, bahan ajar menganalisis dan mengonstruksi makna tersirat teks anekdot disesuaikan dengan karakteristik peserta didik. Bahan ajar yang dikembangkan haruslah berawal dari masalah-masalah kontekstual di kehidupan peserta didik agar peserta didik semakin berpikir kritis terhadap permasalahan yang muncul di kehidupannya. Dengan demikian, bahan ajar yang digunakan peserta didik mampu memecahkan masalah yaitu memberikan pembelajaran yang bermakna bagi peserta didik dan memperjelas pembelajaran berbasis teks.

Dengan memperhatikan temuan di lapangan dan mempertimbangkan alternatif pemecahannya, perlu dikembangkan bahan ajar yang sesusuai dengan kurikulum. Menurut Amri (2010:161) bahan ajar dapat berupa empat bentuk yaitu, (1) bahan ajar pandang, (2) bahan ajar dengar, (3) bahan ajar pandang dengar, dan (4) bahan ajar pembelajaran multimedia interaktif, dan (5) bahan ajar berbasis web (web based learning materials). Adapun yang disajikan dalam pengembangan bahan ajar menganalisis dan mengonstruksi makna tersirat teks anekdot ini berupa bahan ajar pandang. Buku ajar yang disajikan berisi aktivitas literasi sesuai dengan petunjuk dalam Gerakan Literasi Sekolah (GLS), pembangunan konteks, kegiatan belajat, tugas, dan refleksi. Setiap tahap kegiatan belajar disesuaikan dengan pendekatan saintifik yang dikemukakan Kemdikbud (2017: 3-4) bahwa proses pembelajaran pendekatan saintifikmengacu pada pendekatan langkah berpikir saintifikyang mengandung lima langkah yang tidak selalu harus berurut dan seluruhnya ada dalam satu kali pertemuan pembelajaran, yaitu mengamati, menanya, mengumpulkan data, mengasosiasi, mengomunikasikan. Pendekatan ini juga dipadukan dengan model pembelajaran discovery learning dengan sintak pembelajaran yang dikemukakan Kemdikbud (2017: 5) berupa (1) pemberian rangsangan (Stimulation); (2) pernyataan/Identifikasi masalah (Problem Statement); (3) pengumpulan data 
(Data Collection); (4) pembuktian (Verification), dan (5) menarik simpulan/generalisasi (Generalization).

Uraian terkait masalah yang ditemukan di lapangan tersebut, peneliti memiliki keyakinan untuk melalukan penelitian dengan judul Pengembangan Bahan Ajar Teks Anekdot untuk Sekolah Menengah Kejuruan Kelas X. Bahan ajar yang dikembangkan meliputi empat spesifikasi produk, yaitu (1) deskripsi isi, (2) sistematika penyajian, (3) penggunaan bahasa, dan (4) tampilan. Seluruh rangkaian bahan ajar ini diharapkan mampu memberikan solusi terhadap guru dan peserta didik yaitu mengatasi keterbatasan referensi menganalisis dan mengonstruksi makna tersirat teks anekdot.

\section{METODE}

Penelitian ini didasarkan pada metode penelitian dan pengembangan atau Research and Development $(R \& D)$ teori pengembangan dari Borg dan Gall(1983). Penelitian ini menggunakan lima tahap penelitian dari sepuluh tahap penelitian yang dikemukakan Borg and Gall. yaitu (1) penelitian \&pengumpulan data (Reasearch \& Information Collector, (2) perencanaan (Planning), (3) pengembangan draf produk awal (Develope Premliminary Form of Product), (4) uji coba lapangan tahap awal(Preminary Field Testing), (5) revisi produk utama(Main Product Revision).

Uji coba produk dilakukan untuk mengetahui kelayakan produk. Tahap uji coba produk pengembangan ini terdiri atas validasi ahli, guru, dan uji coba lapangan skala kecil dilakukan kepada peserta didik. Tujuan dilakukannya tahap ini adalah untuk mengetahui tingkat kelayakan penyajian produk yang dikembangkan sebelum produk digunakan oleh sasaran. Subjek uji coba (validasi) produk ini terdiri atas tiga kelompok. Pertama,kelompok ahli yang terdiri dari satu orang ahli bahasa dan satu orang uji ahli pembelajaran bahasa. Kelompok ini dilibatkan untuk mengetahui tingkat validasi produk yang dikembangkan yaitu buku ajar. Kedua, uji coba lapangan awal, yaitu penilaian kepraktisan bahan ajar yang dilakukanterhadap satu guru bahasa Indonesia. Ketiga, uji cobadilaksanakan dengan melibatkan peserta didik kelas $\mathrm{X}$ yang berasal dari SMK Negeri 1 Semen Kabupaten Kediri. Adapun Jenis data dalam penelitian ini berupa data verbal deskriptif dan data numerik. Data verbal dibedakan menjadi data verbal tertulis dan tidak tertulis. Data tertulis berupa catatan, komentar, kritik, maupun saran-saran perbaikan yang dituliskan oleh subjek uji pada lembar penilaian yang telah disediakan peneliti. Data tak tertulis berupa informasi lisan yang diperoleh ketika wawancara dan juga masukanmasukan secara lisan dari ahli maupun praktisi. Data verbal tak tertulis kemudian ditranskripsikan. Data numerik diperoleh dari hasil penilaian subjek uji terhadap produk, yaitu berupa skor-skor yang terdapat pada angket penilaian.

Instrumen pengumpulan data dalam penelitian ini terdiri atas angket, pedoman wawancara, dan lembar tes peserta didik. Instrumen angket terdiri atas angket untuk uji ahli, yaitu uji ahli bahasa, ahli pembelajaran bahasa, guru bahasa Indonesia, dan kelompok kecil peserta didik. Instrumen pedoman wawancara digunakan untuk mengklarifikasi secara lisan saran dan komentar tertulis yang belum jelas bagi peneliti. Instrumen pengumpulan data yang digunakan dalam penelitian ini bertujuan untuk mengukur keseluruhan aspek yang berkaitan dengan kevalidan, kepraktisan, kemenarikan, dan keefektifan produk. 
Penelitian ini menggunakan teknik kuantitatif sederhana dan kualitatif. Teknik kuantitatif digunakan untuk menganalisis data kuantitatif yang diperoleh dari angket penilaian produk bahan ajar. Rumus untuk mengolah data per item yaitu $P=\frac{x}{x i} \times 100 \%$ dengan keterangan $\mathrm{P}$ (presentase), $\mathrm{X}$ (jawaban responden dalam satu item), Xi (nilai ideal dalam satu item), dan 100\% (konstanta). Adapun rumus untuk mengolah data secara keseluruhan item $P=\frac{\sum x}{\sum x i} \times 100 \%$ dengan keterangan $\sum_{\mathrm{x}}$ (jumlah keseluruhan responden dalam seluruhan item), $\sum_{\mathrm{xi}}$ ( jumlah keseluruhan skor ideal dalam satu item), dan $100 \%$ (konstanta).Untuk menafsirkan hasil analisis data, digunakan interpretasi sebagai berikut.

Tabel 1 Perhitungan Analisis Data

\begin{tabular}{|c|c|c|c|}
\hline H & $\mathbf{i}$ & $\mathbf{U}$ & \multirow[t]{2}{*}{ Tindak Lanjut } \\
\hline & Presentase & Ku a lifikas i & \\
\hline 4 & $86 \%-100 \%$ & Sangat Layak & Implementasi \\
\hline 3 & $76 \%-85 \%$ & $\begin{array}{lllll}\mathrm{L} & \mathrm{a} & \mathrm{y} & \mathrm{a} & \mathrm{k} \\
\end{array}$ & Implementasi \\
\hline 2 & $-75 \%$ & Cukup Layak & $\begin{array}{llllll}\mathrm{R} & \mathrm{e} & \mathrm{v} & \mathrm{i} & \mathrm{s} & \mathrm{i}\end{array}$ \\
\hline 1 & $\%$ & Kurang Layak & $\begin{array}{llllll}R & \text { e } & \mathrm{V} & \mathrm{i} & \mathrm{s} & \mathrm{i} \\
\end{array}$ \\
\hline
\end{tabular}

Data kualitatif yang berupa data verbal, diperoleh dari wawancara dan catatan tertulis berupa komentar, saran, dan masukan yang tertulis pada angket penilaian. Adapun langkah-langkah untuk menganalisis data verbal ini, yaitu (1) mengumpulkan data verbal tertulis dan lisan pada produk bahan ajar, (2) mentranskrip data verbal tertulis dan lisan, (3) menghimpun, menyeleksi, mengklasifikasikan data verbal tulis dan hasil transkrip verbal lisan berdasarkan kelompok uji, dan (4) menganalisis data dan merumuskan simpulan hasil analisis sebagai dasar untuk melakukan tindakan terhadap produk bahan ajar.

\section{HASIL}

\section{Deskripsi Produk}

Spesifikasi produk bahan ajar yang dikembangkan dalam empat aspek. Empat aspek tersebut meliputi(1) aspek isi, (2) aspek sistematika, (3) aspek bahasa, dan (4) aspek tampilan.

Isi bahan ajar menganalisis dan mengonstruksi makna tersirat teks anekdot terbagi menjadi tiga bagian, yaitu (1) pengantar, (2) kegiatan inti, (3) refleksi.Sistematika produk bahan ajar menganalisis dan mengonstruksi makna tersirat teks anekdot untuk peserta didik kelas X SMK disajikan secara berurutan.

Sistematika produk bahan ajar disajikan dalam kegiatan utama yang diberikan pada bahan ajar menganalisis dan mengonstruksi makna tersirat teks anekdot. Pertama, kegiatan awal berupa pengantar yang didalamnya terdapat aktiviats literasi dan pembangunan konteks. Kedua, kegiatan inti yang disesuaikan dengan kompetensi dasar pada kurikulum 2013 revisi 2017 yaitu (1) menganalisis teks anekdot dari aspek makna tersirat dengan kegiatan belajar 1 dan kegaiatan belajar , serta tiga tugas di dalamnya, dan (2) mengonstruksi makna tersirat dalam sebuah teks anekdot dengan kegiatan belajar 1,2 dan 3, serta tiga tugas di dalamnya.

Bahan ajar menganalisis dan mengonstruksi makna tersirat teks anekdot ini menggunakan ragam bahasa baku bahasa indonesia. Selain itu, disajikan pula 
bahasa yang komunikatif dan interaktif yang tertuang dalam setiap kegiatan pembelajaran. Bahan ajar ini juga menggunakan kalimat perintah yang bertujuan untuk mengajak peserta didik aktif dalam kegiatan pembelajaran. Setiap instruksi yang disajikan dalam setiap subbab juga didominasi oleh kalimat tanya dan kalimat perintah. Dominasi kedua jenis kalimat ini membuktikan bahwa produk komunikatif dan interaktif. Kata 'kamu' untuk menyebut peserta didik sebagai pembelajar menambah aspek bahasa semakin komunikatif.

Produk bahan ajar menganalisis dan mengonstruksi makna tersirat teks anekdot ditampilkan dalam bentuk buku ajar. Tampilan buku ajar dilihat dari berbagai segi, mulai dari warna, jenis huruf, hingga pemilihan gambar. Warna bahan ajar untuk kelas X SMK didominasi oleh warna biru, ungu, orange, dan putih. Keempat warna tersebut dipilih berdasarkan permintaan peserta didik saat melakukan studi pendahuluan. Huruf yang dipilih dalam bahan ajar adalah Calibri (body) dengan ukuran huruf 12. Jenis huruf tersebut dipilih sesuai dengan tingkat keterbacaan peserta didik. Pemilihan gambar pada sampul bahan ajar menganalisis dan mengonstruksi makna tersirat teks anekdot mengilustrasikan materi yang disampaikan. Penyajian buku ajar dicetak pada kertas ukuran A5 $(14,8 \mathrm{~cm} \times 21 \mathrm{~cm})$.

\section{Hasil Uji Coba}

Dalam analisis data, dipaparkan secara rinci hasil uji kelayakan bahan ajar mulai dari ahli bahasa, ahli pembelajaran bahasa, guru, hingga siswa kelas X SMK. Uji kelayakan pada ahli bahasa dan ahli pembelajaran bahasa bertujuan untuk menilai tingkat validitas bahan ajar sebelum digunakan dalam proses pembelajaran di lapangan. Uji kelayakan pada guru bertujuan untuk menilai tingkat kepraktisan dari kemudahan guru dalam menggunakan bahan ajar di kelas. Uji kelayakan pada siswa bertujuan untuk menilai tingkat kemenarikan produk dari ketertarikan siswa dalam belajar menggunakan bahan ajar. Uji kelayakan pada siswa juga menilai aspek keefektifan produk yang dilihat dari ketercapaian tujuan pembelajaran menganalisis dan mengonstruksi makna tersirat teks anekdot setelah dilaksanakan uji coba bahan ajar. Paparan analisis data uji kelayakan dijelaskan sebagai berikut.

Pertama komponen deskripsi isi dari ahli bahasa.Komponen deskripsi isi dari ahli bahasa yang dapat dilihat pada tabel 4.1 terdapat dua puluh poin. Poin $5,7,15$, dan 16 memeroleh skor dengan presentase sempurna yaitu $100 \%$. Poin 1 , $2,3,4,6,8,9,10,11,12,13,14,17,18,19$, dan 20 memeroleh skor yang relatif sama yaitu memeroleh presentase $75 \%$. Secara keseluruhan, pada komponen isi oleh ahli bahasa memeroleh skor dengan presentase $80 \%$. Skor tersebut layak untuk diimplementasikan. Selanjutnya akan dideskripsikan hasil uji ahli pembelajaran bahasa. Komponen deskripsi isi dari ahli pembelajaran bahasa yang dapat dilihat pada tabel 4.2 terdapat delapan belas poin. Hasil uji ahli pembelajaran bahasamemeroleh skor dengan presentase $75 \%$. Pada komponen isi perlu dikualifikasikan cukup layak dan perlu revisi. Setelah dilakukan revisi deskripsi isi dari validasi uji ahli dengan ahli bahasa dan ahli pembelajaran bahasa, selanjutnya dilakukan uji coba pada guru bahasa Indonesia kelas X SMK. Berikut disajikan data hasil uji coba komponen deskripsi isi dengan guru kelas $\mathrm{X}$ SMK Negeri 1 Semen Kabupaten Kediri.Komponen deskripsi isi dari guru yang dapat dilihat pada tabel 4.3 terdapat empat poin. Keenam poin memeroleh skor 
dengan presentase $75 \%$. Dengan demikian, terhimpun poin satu sampai dengan enam dikualifikasikan cukup layak dan perlu dilakukan revisi. Setelah dilakukan revisi pada komponen isi dari guru bahasa Indonesia kelas $\mathrm{X}$, berikut komponen deskripsi isi dari siswa yang dapat dilihat pada tabel 4.4 terdapat tiga poin. Poin satu dan tiga memeroleh skor dengan presentase $81,25 \%$. Sehingga, pada poin satu dan tiga memiliki kualifikasi layak dan dapat diimplementasikan. Adapun poin dua memeroleh skor dengan presentase $75 \%$ memiliki kualifikasi cukup layak dan revisi. Dengan demikian, keseluruhan poin terhimpun skor dengan presentase $77,08 \%$, sehingga produk ini layak dan dapat diimplementasikan dalam pembelajaran.

Komponen penilaian yang kedua adalah sistematika penyajianKomponen sistematika penyajian dari ahli bahasa yang dapat dilihat pada tabel 4.5 terdapat dua poin. Masing- masing poin memeroleh skor yang sama yaitu dengan presentase $100 \%$. Dapat disimpulkan bahwa sistematika penyajian dari ahli bahasa sangat layak untuk diimplemetasikan dalam pembelajaran. Selanjutnya akan dideskripsikan hasil uji ahli pembelajaran bahasa. Komponen sistematika penyajian dari ahli pembelajaran bahasa yang dapat dilihat pada tabel 4.6 terdapat aspek dua poin. Presentase $100 \%$ diperoleh masing-masing poin, sehingga sistematika penyajian layak untuk diimplementasikan.Setelah dilakukan revisi sistematika penyajian dari validasi uji ahli dengan ahli bahasa dan ahli pembelajaran bahasa, selanjutnya dilakukan uji coba pada guru bahasa Indonesia kelas X SMK. Berikut disajikan data hasil uji coba komponen deskripsi isi dengan guru kelas X SMK Negeri 1 Semen Kabupaten Kediri.Komponen sistematika penyajian dari guru yang dapat dilihat pada tabel 4.7 terdapat dua poin. Kedua poin tersebut memeroleh sekor dengan presentase $75 \%$, sehingga, sistematika penyajian dikategorikan cukup layak dan perlu dilakukan revisi.Setelah dilakukan revisi terhadap sistematika penyajian oleh guru bahasa Indonesia kelas $\mathrm{X}$, berikut disajikan data hasil uji coba komponen sistematika penyajian oleh siswa kelas $\mathrm{X}$ SMK.Komponen sistematika penyajian dari siswa yang dapat dilihat pada tabel 4.8 terdapat dua poin. Poin pertama memeroleh skor dengan presentase 93,75\%, sehingga pada poin ini dikualifikasikan sangat layak dan dapat diimplementasikan dalam pembelajaran. Adapun poin kedua memeroleh skor dengan presentase $75 \%$ yang dikulaifikasikan cukup layak dengan revisi. Dengan demikian, kesimpulan dari sistematika penyajian ini diperoleh skor dengan dengan presentase 84,37\% yang dikualifikasikan layak dan dapat diimplementasikan dalam pembelajaran.

Komponen penilaian yang ketiga adalah ragam bahasa. Komponen ragam bahasa dari ahli bahasa yang dapat dilihat pada tabel 4.9 terdapat tiga poin. Ketiga poin memeroleh skor dengan presentase yang sama yaitu $75 \%$. Pada komponen ini, perlu adanya tahap revisi. Selanjutnya akan dideskripsikan hasil uji ahli pembelajaran bahasa. Komponen ragam bahasa dari ahli pembelajaran bahasa yang dapat dilihat pada tabel 4.10 terdapat tiga poin. Ketiga memeroleh skor sama yaitu presentase $75 \%$, sehingga perlu dilakukan revisi pada komponen ini.Setelah dilakukan revisi ragam bahasa dari validasi uji ahli dengan ahli bahasa dan ahli pembelajaran bahasa, selanjutnya dilakukan uji coba pada guru bahasa Indonesia kelas X SMK. Berikut disajikan data hasil uji coba komponen deskripsi isi dengan guru kelas X SMK Negeri 1 Semen Kabupaten Kediri.Komponen ragam bahasa dari guru yang dapat dilihat pada tabel 4.11 terdapat tiga poin. Ketiga poin tersebut memeroleh skor dengan presentase $75 \%$. Sehingga, komponen ragam 
bahasa ini dikualifikasikan cukup layak dan perlu revisi pada penggunaan bahasa. Setelah dilakukan revisi pada ragam bahasa, berikut komponen ragam bahasa dari siswa yang dapat dilihat pada tabel 4.12 terdapat satu poin. Poin tersebut memeroleh skor dengan presentase $81,25 \%$ yang dikualifikasikan layak dan komponen ragam bahasa ini dapat diimplementasikan layak dalam pembelajaran.

Komponen penilaian yang keempat adalah tampilan. Komponen tampilan dari ahli bahasa yang dapat dilihat pada tabel 4.13 terdapat sembilan poin. Poin 1 dan 4 memeroleh skor dengan presentase $50 \%$. Poin 2, 3, 5, 6, 7, 8, dan 9 memeroleh skor yang sama yaitu $75 \%$. Secara keseluruhan presentase diperoleh 69,4 \%, sehingga perlu direvisi pada komponen ini.Selanjutnya akan dideskripsikan hasil uji ahli pembelajaran bahasa.Komponen tampilan dari ahli pembelajaran bahasa yang dapat dilihat pada tabel 4.14 terdapat sembilan poin. Kesembilan poin memeroleh skor sama yaitu presentase $75 \%$, sehingga perlu dilakukan revisi pada komponen ini.Setelah dilakukan revisi tampilan dari validasi uji ahli dengan ahli bahasa dan ahli pembelajaran bahasa, selanjutnya dilakukan uji coba pada guru bahasa Indonesia kelas X SMK. Komponen tampilan dari guru yang dapat dilihat pada tabel 4.15 terdapat delapan poin. Ketiga poin tersebut memeroleh skor dengan presentase $75 \%$. Sehingga, komponen tampilan ini dikualifikasikan cukup layak dan perlu revisi pada penggunaan bahasa. Setelah dilakukan revisi pada tampilan, berikut komponen tampilan dari siswa yang dapat dilihat pada tabel 4.16 terdapat enam poin. Poin satu dan empat memeroleh skor dengan presentase $87,5 \%$, sehingga termasuk dalam kualifikasi sangat layak dan dapat diimplementasikan. Poin dua dan tiga memeroleh skor sempurna dengan presentase $100 \%$, sehingga layak dan dapat diimplementasikan. Selanjutnya, poin lima dan enam memeroleh skor dengan presentase 93,75 \% yang dikualifikasikann sangat layak dan dapat diimplementasikan dalam pembelajaran. Dengan demikian, kesimpulan pada komponen tampilan, produk ini memeroleh skor dengan presentase 93,75\%. Skor tersebut dikualifikasikan sangat layak dan dapat diimplementasikan dalam pembelajaran.

\section{PEMBAHASAN}

Muslich (2010: 292-293) mengutarakan tiga kriteria kelayakan isibahan ajar yang harus dipenuhi bahan ajar, yakni (1) kesesuaian uraian materi dengan standar kompetensi (SK) dan kompetensi dasar (KD) yang terdapat dalam kurikulum mata pelajaran yang bersangkutan, (2) keakuratan materi, dan (3)materi pendukung pembelajaran.

Deskripsi isi bahan ajar menganalisis dan mengonstruksi makna tersirat teks anekdot terbagi menjadi tiga bagian, yaitu (1) pengantar, (2) kegiatan inti, (3) refleksi. Kegiatan belajar diawali dengan aktivitas literasi yang dimulai dengan membaca wacana berjudul Generasi X, Y, Z oleh Dr. Sigit Sanyata, M.Pd. (Pemimpin Redaksi Pewara Dinamika UNY, 2017). Pemilihan wacana sengaja dibuat beda dengan materi utama yaitu teks anekdot dengan alasan disesuaikan dengan petunjuk pada kurikulum 2013 untuk menyediakan bahan bacaan selain materi. Aktivitas literasi untuk mendukung program Gerakan Literasi Sekolah (GLS) pada Kurikulum 2013 yaitu dengan membiasakan membaca selama 15 menit di setiap awal pembelajaran. Penyediaan aktivitas literasi ini dapat dimanfaatkan oleh guru jika mata pelajaran bahasa Indonesia berada pada jam 
pertama. Kegiatan berikutnya yaitu pembangunan konteks yang berisi pengantar materi menuju materi utama yaitu teks anekdot.Bagian kedua yaitu kegiatan inti. Kegiatan inti ini difokuskan pada Indikator Pencapai Kompetensi (IPK). Tujuan utama pembelajaran ini yaitu (1) peserta didik dapat menganalisis teks anekdot dari aspek makna tersirat dan (2) peserta didik dapat mengonstruksi makna tersirat dalam sebuah teks anekdot. Tujuan pembelajaran pertama diawali dengan kegiatan belajar mendata pokok-pokok teks anekdot. Teks meliputi teks 1 dan teks 2. Siswa diarahkan untuk membaca teks 1 beserta tips untuk berkonsentrasi dalam memahami teks. Teks yang disediakan berjudul KUHP dalam Anekdot, dilanjutkan dengan kegiatan tanya-jawab terkait isi teks 1. Kegiatan selanjutnya yaitu peserta didik diarahkan untuk mendata pokok-pokok teks anekdot pada teks 2 berjudul Anekdot Hukum Peradilan. Adapun aspek yang didata ditampilan dalam sebuah kolom (tugas 1) meliputi pokok-pokok teks anekdot, bukti kritik terhadap suatu masalah atau tokoh publik, dilanjutkan dengan tugas 2 yaitu masalah yang dibahas, unsur humor, dan makna tersirat yang disampaikan. Kegiatan belajar kedua pada tujuan pembelajaran pertama yaitu mengidentifikasi penyebab kelucuan teks anekdot. Teks yang akan dianalisis oleh peserta didik yaitu teks 1 pada kegiatan belajar 1. Aktivitas pada kegiatan ini siswa mengidentifikasi penyebab-penyebab kelucuan.Kegiatan mengonstruksi makna tersirat dalam sebuah teks anekdot meliputi (1) membandingkan anekdot dengan humor, (2) menganalisis kritik yang disampaikan dalam anekdot, dan (3) menyimpulkan makna tersirat dalam anekdot. Kegiatan belajar 1 diawali dengan penggambaran perbedaan antara humor dan anekdot. Peserta didik akan mengidentifikasi perbedaan dan persamaan humor atau cerita lucu dengan anekdot. Kegiatan ini disediakan teks 1 berjudul Dosen yang juga Menjadi Pejabat, teks 2 berjudul Karena Kamu Laki-laki, dan teks 3 berjudul Lift. Bahan ajar akan menyediakan kolom untuk mengisi perbedaan humor dengan anekdot dari aspek isi, ide cerita, fungsi komunikasi, dan persamaan humor dan anekdot. Kegiatan belajar 2 yaitu menganalisis kritik yang disampaikan dalam anekdot. Peserta didik diberi penjelasan terkait tujuan teks anekdot dan penyampaikan kritik atau aspek sindiran dalam anekdot. Bahan ajar ini juga menyediakan contoh penyampaian kritik dari teks Dosen yang juga Menjadi Pejabat. Aspek yang dicontohkan berupa makna idiomatis dari kata, frase, klausa, atau kalimat dari teks Dosen yang juga Menjadi Pejabat. Tugas peserta didik pada kegiatan ini yaitu menentukan kata, frase, klausa, atau kalimat yang menjadi aspek makna idiomatis dari kritik yang disampaikan dalam wacana KUHP Hukum Peradilan. Kegiatan belajar 3 yaitu menyimpulkan makna tersirat dalam anekdot. Peserta didik dipandu untuk memahami cara menyimpulkan suatu kritik dalam anekdot. selanjutnya, peserta didik memilih teks anekdot yang tersedia untuk disimpulkan melalui kolom yang tersedia.Kegiatan penutup, yaitu Refleksi. Siswa diminta untuk membuka-buka kembali tiap kegiatan belajar untuk dikuatkan kembali bagian yang belum dukuasai. Bagain ini disediakan pula rangkuman dari materi belajar.

Panen (2001:2) mengungkapkan komponen utama dalam sistematika penyajian meliputi (1) tinjauan kompetensi, (2) pendahuluan, (3) bagian inti, (4) penutup, (5) daftar pustaka, dan (6) lampiran.Sistematika produk bahan ajar menganalisis dan mengonstruksi makna tersirat teks anekdot untuk siswa kelas X SMK disajikan secara berurutan, yaitu (1) halaman depan, (2) halaman sampul 
kedua, (3) kata pengantar, (4) motivasi belajar, (5) kompetensi yang harus dicapai, (6) daftar isi, (7) pengantar (aktivitas literasi dan pembangunan konteks belajar), (8) kegiatan inti (kegiatan belajar sesuai dengan indikator pencapai kompetensi, petunjuk tugas, dan tugas),(9) kegiatan akhir (refleksi, keterampilan berbahasa yang dikuasai peserta didik setelah pembelajaran, catatan evaluasi guru, dan rangkuman), (10) daftar pustaka, (11) biodata penulis.Tujuannya adalah untuk menggiring siswa memahami tentang makna tersirat teks anekdot. Terdapat tiga kegiatan utama yang diberikan pada bahan ajar menganalisis dan mengonstruksi makna tersirat teks anekdot.Pertama, kegiatan awal berupa pengantar yang didalamnya terdapat aktiviats literasi dan pembangunan konteks. Kedua, kegiatan inti yang disesuaikan dengan kompetensi dasar pada kurikulum 2013 revisi 2017 yaitu (1) menganalisis teks anekdot dari aspek makna tersirat, dan (2) mengonstruksi makna tersirat dalam sebuah teks anekdot. Kompetensi dasar pertama terdapat kegiatan belajar 1 dan kegaiatan belajar 2. Kegiatan belajar 1 disediakan tugas 1 dan 2 untuk proses belajar untuk mendata pokok-pokok teks anekdot. Kegiatan belajar 2 disediakan satu tugas untuk mengidentifikasi penyebab kelucuan teks anekdot. Kompetensi dasar kedua terdapat kegiatan belajar 1,2 dan 3. Kegiatan belajar 1 disediakan satu tugas untuk membandingkan anekdot dan humor. Kegaiatan belajar 2 disediakan satu tugas untuk menganalisis kritik yang disampaiakn dalam anekdot. Kegiatan belajar 3 disediakan satu tugas untuk menyimpulkan makna tersirat dalam anekdot. Ketiga, refleksi yang memuat kegiatan merefleksi pembelajaran yang telah dilakukan. Selanjutnya, peserta didik diarahkan untuk menentukan bagian kegiatan belajar yang belum dikuasai. Disediakan pula rangkuman materi belajar pada bagian refleksi ini.

Muslich (2010:303-305) memaparkan beberapa kriteria kelayakan bahasa yang baik, diantaranya (1) kesesuaian pemakaian bahasa dengan perkembangan intelektual, sosial, dan emosional peserta didik, (2) pemakaian bahasa yang komunikatif, dan (3) keruntutan dan keterpaduan alur pikir. Bahan ajar menganalisis dan mengonstruksi makna tersirat teks anekdot ini menggunakan ragam bahasa baku bahasa indonesia. Selain itu, disajikan pula bahasa yang komunikatif dan interaktif yang tertuang dalam setiap kegiatan pembelajaran. Bahan ajar ini juga menggunakan kalimat perintah yang bertujuan untuk mengajak siswa aktif dalam kegiatan pembelajaran. Setiap instruksi yang disajikan dalam setiap subbab juga didominasi oleh kalimat tanya dan kalimat perintah. Dominasi kedua jenis kalimat ini membuktikan bahwa produk komunikatif dan interaktif.

Muslich (2010:312) memaparkan kriteria kelayakan tampilan perlumempertimbangkan (1) jenis dan ukuran huruf, (2) penataan halaman dansistem penomeran, (3) penggunaan ilustrasi dan warna bahan ajar, dan (4) desainsampul bahan ajar. Bahan ajar ini sudah memenuhi semua kriteria kelayakan tersebut.Produk bahan ajar menganalisis dan mengonstruksi makna tersirat teks anekdot ditampilkan dalam bentuk buku ajar. Tampilan buku ajar dilihat dari berbagai segi, mulai dari warna, jenis huruf, hingga pemilihan gambar. Warna bahan ajar untuk kelas X SMK didominasi oleh warna biru, ungu, orange, dan putih. Keempat warna tersebut dipilih berdasarkan permintaan peserta didik saat melakukan studi pendahuluan. Huruf yang dipilih dalam bahan ajar adalah Calibri (body) dengan ukuran huruf 12. Jenis huruf tersebut dipilih sesuai dengan tingkat keterbacaan peserta didik. Pemilihan gambar pada sampul bahan ajar 
menganalisis dan mengonstruksi makna tersirat teks anekdot mengilustrasikan materi yang disampaikan. Penyajian buku ajar dicetak pada kertas ukuran A5 $(14,8 \mathrm{~cm} \times 21 \mathrm{~cm})$.

\section{KESIMPULAN}

Produk bahan ajar ini memiliki keunggulan dan kelemahan. Keunggulan bahan ajar ini mampu membantu peserta didik dalam menganalisis dan mengonstruksi makna tersirat teks anekdot. Kegiatan belajar dan tugas yang disajikan disesuaikan dengan pendekatan dan model pembelajaran yang dipakai, yaitu pemaduan pendekatan saintifik dengan model pembelajaran discovery learning. Pendekatan da model pembelajaran tersebut sangat sesuai untuk menuntaskan indikator pencapai kompetensi pada materi menganalisis dan mengonstruksi makna tersirat teks anekdot kurikulum 2013. Sintak model pembelajaran discovery learning terinput dalam setiap kegiatan belajar. Selain itu, teks anekdot yang dianalisis mencakup berbagai bidang, seperti politik, layanan umum, dan hukum. Disamping keunggulan tersebut, bahan ajar ini juga memiliki kelemahan produk, yaitu dalam penerapan pembelajaran, peserta didik kurang terbantu dalam memahami materi atau gagasan-gagasan terkait definisi, jenis, perbedaan humor dan anekdot. Peserta didik diajak untuk membangun sendiri konsep belajarnya.

\section{SARAN}

Bahan ajar teks anekdot untuk sekolah menengah kejuruan kelas $\mathrm{X}$ dapat dijadikan alternatif bagi guru kelas $\mathrm{X}$ untuk mengajarkan kompetensi dasar menganalisis dan mengonstruksi maknatersirat teks anekdot. Guru dapat mengoptimalkan penggunaan bahan ajar dengan terus mendorong peserta didik dan menumbuhkan kepekaan terhadap berbagai bidang kehidupan untuk dapat memberikan kritik melalui humor.

Bahan ajar teks anekdot untuk sekolah menengah kejuruan kelas X juga dapat digunakan sebagai alternatifuntuk belajar di rumah, khususnyadalam hal menganalisis dan mengonstruksi makna tersirat teks anekdot.Hal tersebut karena bahan ajar yangmeyajikan teks anekdot dalam berbagai bidang kehidupan, termasuk layanan publik. Tahapan-tahapanpembelajaran di dalam bahan ajar ini disesuaikan dengan pendekatan berpikir kritis.

DAFTAR RUJUKAN

Amri, S \& Lif, K. 2010. Konstruksi Pengembangan Pembelajaran.Jakarta: Prestasi Pustaka.

Kementerian Pendidikan dan Kebudayaan. 2017. Analisis Penerapan Model Pembelajaran. Modul Bimbingan Teknis Implementasi Kurikulum 2013 Sekolah Menengah Kejuruan: 3-25.

Muslich, M. 2010. Text Book Writing: Dasar-Dasar Pemahaman Pemakaian BukuTeks. Jogjakarta: Ar-Ruzz Media.

Pannen, P., \& Purwanto. 2001. Penulisan Bahan Ajar. Jakarta: PAU-PPAI Universitas Terbuka.

Suherli. 2016. Buku Guru Bahasa Indonesia. Pusat Kurikulum dan Perbukuan, Balitbang, Kemdikbud. 